DOI: https://doi.org/10.31933/dijemss.v2i4 Received: $24^{\mathrm{h}}$ January 2021, Revised: $18^{\text {th }}$ March 2021, Publish: $18^{\text {th }}$ March 2021

\begin{tabular}{|c|c|c|}
\hline PUNASTISTR & $\begin{array}{l}\text { DIJEMSS } \\
\text { DINASTI INTERNATIONAL JOURNAL } \\
\text { OF EDUCATION MANAGEMENT AND } \\
\text { SOCIAL SCIENCE }\end{array}$ & $\begin{array}{r}\text { https://dinastipub.org/DIJEMSS } \\
\text { editor@dinastipub.org } \\
08117401455\end{array}$ \\
\hline
\end{tabular}

\title{
IMPLEMENTATION HUMAN RESOURCE MANAGEMENT IN IMPROVING COMPETITIVE ADVANTAGE of PT CSI
}

\author{
Rina Trinovianti ${ }^{1}$, Sangkala Ruslan ${ }^{2}$ \\ ${ }^{1}$ Universitas Mercu Buana, Jakarta, Indonesia, rina.trinovianti@yahoo.com \\ ${ }^{2}$ Universitas Mercu Buana, Jakarta, Indonesia, dr_ruslan_se@yahoo.com
}

Corresponding Author: Rina Trinovianti

\begin{abstract}
This research aims to analyze the implementation of the integration process of the company's strategic plan and HRD strategic plan in increasing competitive advantage in PT CSI. The research data is collected from in-depth interviews and secondary data as well as primary data from HRD in 2019. Qualitative research methods with approaches case studies are used in this study. The results of the study found that the implementation of Human Resource Management has not been oriented towards comprehensive investment. It is proven that HRD is still considered a cost center, even though there has been an integration and adaptation of the entire process of increasing competitive advantage. HRD companies have been involved in the planning process. The day-to-day practice of Human Resource Management does not appear to fully describe the integration with the needs of organizational strategy. The results also show that at the practical level HRD has a two-way relationship with policy makers, meaning that the problems and impacts that arise in HR management are considered in the strategic plan formulation process.
\end{abstract}

Keywords: Program Integration, Strategic Plan, MC Kennsy 7S Framework, HRD, Competitive Advantage

\section{INTRODUCTION}

One of the requirements for a company to be effective in a competitive environment is the company's ability to manage its human resources as good as possible. Companies that have a highly competitive advantage will place the role of human resources in a very important position and not be ignored. Thus, the company must have smart and precise people because without the right people. The company strategy cannot be implemented. Therefore, the company's ability to make and choose the right strategies in managing human resources is very important because it will have an impact on the realization of its short-term and long-term goals. 
Human resources can be an advantage for a company in maintaining its competitive advantage and to seize and expand new market segments. Human resources cover the entire field of management, personal management and organizational systems, and are also one of the most important inputs in the company's operational activities, both in sectors that produce goods and services. Therefore, operational success will be determined by effective and efficient human resource management (Kaswan, 2012: 9).

Human resource management as a competitive advantage (Rayadi, 2012) is a wellplanned management and utilization of human resources to create superior performance, to achieve company goals in a competitive market. Companies need to focus on developing the quality of their human resources because human resources can increase their competitive advantage.

PT CSI is one of the producers that produce steel balls, and is currently increasing its role in import substitution of steel ball products. The company supplies steel balls to a number of mining companies and a number of domestic cement factories by expanding their business and inaugurating additional factories in the Cilegon area, Banten. The company uses an expansion strategy to maintain the company's sustainable competitive advantage. This strategy is not carried out only through operational activities. Most of the PT CSI's management innovations, namely total quality, just-in-time, benchmarking, business process reengineering, outsourcing is about operational effectiveness. Through this management innovation the company can do something better than its competitors. However, this cannot guarantee sustainable competitive advantage without undertaking human resource management planning that is in line with the company's strategic planning.

Data obtained from the company's HRD need to adjust the strategic plan for managing human resources effectively and efficiently. Human resource development that is carried out consistently and continuously through a process of accumulation and utilization of human capital has a strategic role in efforts to improve the company's performance. Implementing and enforcing human resource management that is oriented towards investing in human resources at the organizational level so as to contribute to the continuous improvement of the company's competitiveness. The Company is also obliged to manage the diversity of human resources in the organization, in order to bring the company towards achieving its goals, through individual strategic efforts, and organizational efforts or organizational approaches.

The formulation and implementation of strategic human resource management practices is not a Human Resource management model that conforms to the organizational strategy orientation. Companies need to develop strategic Human Resource Management (human capital investment oriented) which can act as a strategic partner for the organization to make adjustments to various changes in the company's strategy.

\section{LITERATURE REVIEW \\ Human Capital in Organizations}

In connection with the human capital of Robert L. Mathis, John H. Jackson (2012) states that it is not only related to the physical people in the organization but includes the abilities, 
capabilities and skills that are brought and contribute to organizational success. In other words, human capital is the collective value of the abilities, knowledge, skills, life experiences, and motivation of the organizational workforce.

The abilities, thoughts, knowledge, creativity, and decision making contributed by people in this organization are known as intellectual capita. Companies with high intellectual capital can have technical and research employees who create new patented products, and develop product sets for special uses. All of these organizational contributions illustrate the potential value of human and intellectual capital

Robert L. Mathis, John H. Jackson (2012) made a fairly complete HR Management diagram as a human resource management model. HR management must focus on contributing to organizational success. The key to improving organizational performance is ensuring human resource activities support organizational efforts that focus on productivity, service, and quality.

Strategic HR Management; As part of maintaining organizational competitiveness, HR effectiveness can be increased through the use of HR measurement and HR technology. Through HR planning, managers anticipate employee supply and demand and employee retention.

a) Equal Job Opportunities; compliance with labor laws and regulations affects all other HR activities. The diversity of the workforce creates additional challenges.

b) Staffing; to provide an adequate supply of talented and qualified individuals to fill jobs in an organization.

c) Productivity: total output per employee, continuous increase in productivity. The productivity of human resources is influenced by management efforts, programs and systems.

d) Quality: the quality of the products and services provided affects the success of the organization in the long run. Emphasis on quality requires constant changes aimed at improving work processes.

e) Service: HR management considerations should be included when identifying service barriers and redesigning operational processes. Involving all employees, not just managers, in problem solving often requires changes in company culture, leadership styles, and HR policies and practices. HR activities that are carried out are:

a. HR Planning and Analysis:

b. Equal Employment Opportunities

c. Staffing

d. HR Development

e. Compensation and benefits

f. Health, Safety and Security

g. Employee and Labor / Management Relations

The difference between operational and strategic roles exists in a number of areas of HR, explained by Robert L. Mathis, John H. Jackson (2012) as shown in Figure 2.2. Strategic HR roles require HR professionals to be proactive in dealing with business realities and focus on future business needs, such as workforce planning, compensation strategies, and HR performance. Many executives, managers, and HR professionals increasingly see the need for HR management to be a greater strategic contributor to the success of an organization's "business". 


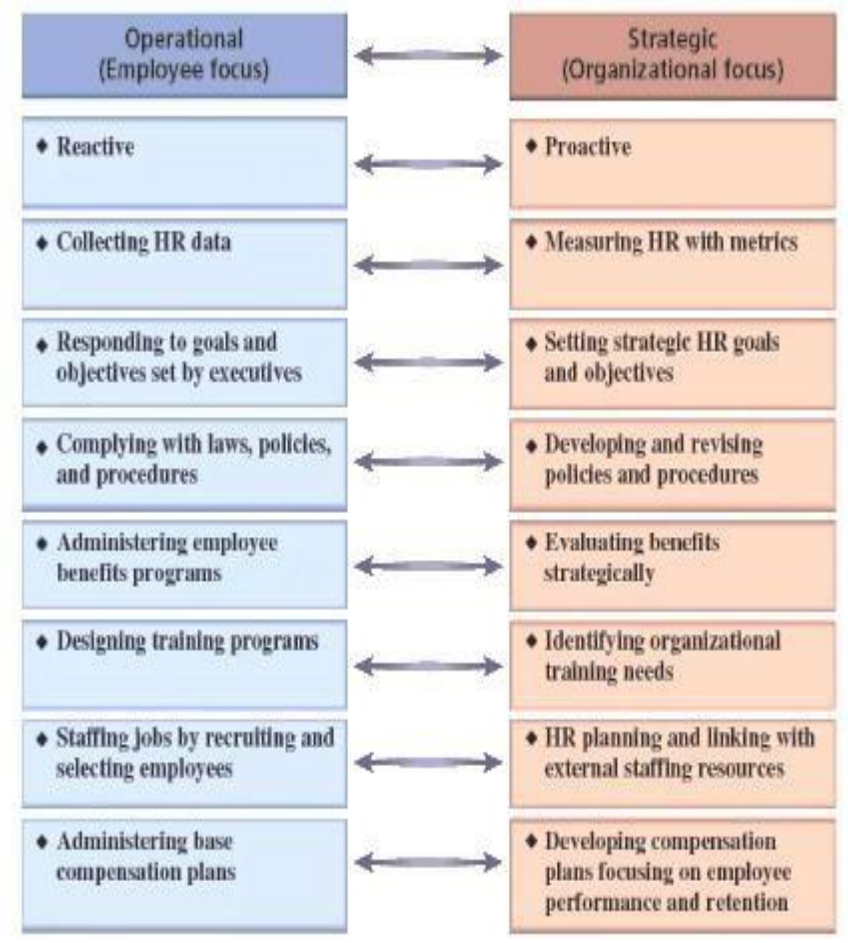

Figure. 1

Factors Affecting Strategic HR Management

Strategic HR management refers to using employees to gain or maintain a competitive advantage. Figure 2.1 shows the factors that influence strategic HR management. Since business strategy influences HR plans and policies, consideration of human resource issues must be part of the strategy formulation process. It is important to identify competitive advantage opportunities that suit existing employees or to assess strategic alternatives given the organization's current human resource capabilities. HR managers should scan the environment to find out what workforce skills are available and what are not. HR professionals should also be able to estimate waiting times to match a workforce shortage or surplus. In short, HR must be involved in implementing a strategy that influences and is influenced by people.

\section{Integration of HR Management in the Strategic Management Process}

The success of the Strategic Management process depends on the extent to which the HR Management Function is involved. In relation to the strategy formulation process, the involvement of the role of HR Management varies in level according to the level of integration or the relationship between the strategic planning function and the HR management function. Noe, Hollenbeck, Gerhart, Wright, (2012) emphasized that there are four levels of integration or relationship between the strategic planning function and the HR management function, namely as follows: 
a) Administrative relations, low level of integration, attention of HR Management to focus on daily activities, separate from elements of the strategic management process.

b) One-way relationship, the strategic plan is informed to the HR management department, so that they dare to design a system or program that supports the achievement of the strategy.

c) Two-way Relationship, problems and impacts on HR are considered in strategy formulation. HR strategic planning and strategic functions are interconnected and dependent through;

1) The strategic planning is informed to the HR Management section.

2) HR management functions to analyze problems and the impact of the strategic plan on HR and then inform the strategic planning division.

3) The planning team makes strategic decisions and informs HR Management to develop systems and / or programs that support the implementation of the strategic plan.

d) Integrative Relationships, are dynamic in nature and interact continuously in various aspects. HR management is planned and compiled directly into the process of strategic planning formulation and strategy implementation.

The four levels of integration or the relationship between the strategic planning function and the HR management function, of course, the most ideal relationship in supporting the company's strategic management process is Integrative Relationships. How HR Management can provide a competitive advantage in the Strategic Management Process is described in the following two sections:

a) There are five main elements of the HR Management Process that relate to strategy formulation, namely mission - objectives - external analysis - internal analysis - strategy selection. External analysis requires input related to human resources, many opportunities and threats to the external environment related to human resources such as labor market conditions, government regulations regarding labor, and so on. Likewise, with internal analysis. Analysis of internal strengths and weaknesses requires input related to $\mathrm{HR}$ because $\mathrm{HR}$ is an important company asset. By considering input related to HR, the strategy planning team can consider all business issues related to HR before making strategic choices so that they can make the most effective strategy choices.

b) The Role of HR Management in the Strategy Implementation Process After the choice of strategy is implemented, HR Management must take an active role in implementing it. There are five important variables that determine the success of strategy implementation, namely organizational structure, task design, selection, training and human resource development, reward systems, and information systems.

\section{The Framework}

The HR planning process runs simultaneously and interactively with the company's strategic planning in increasing the competitive advantage of PT. CSI 


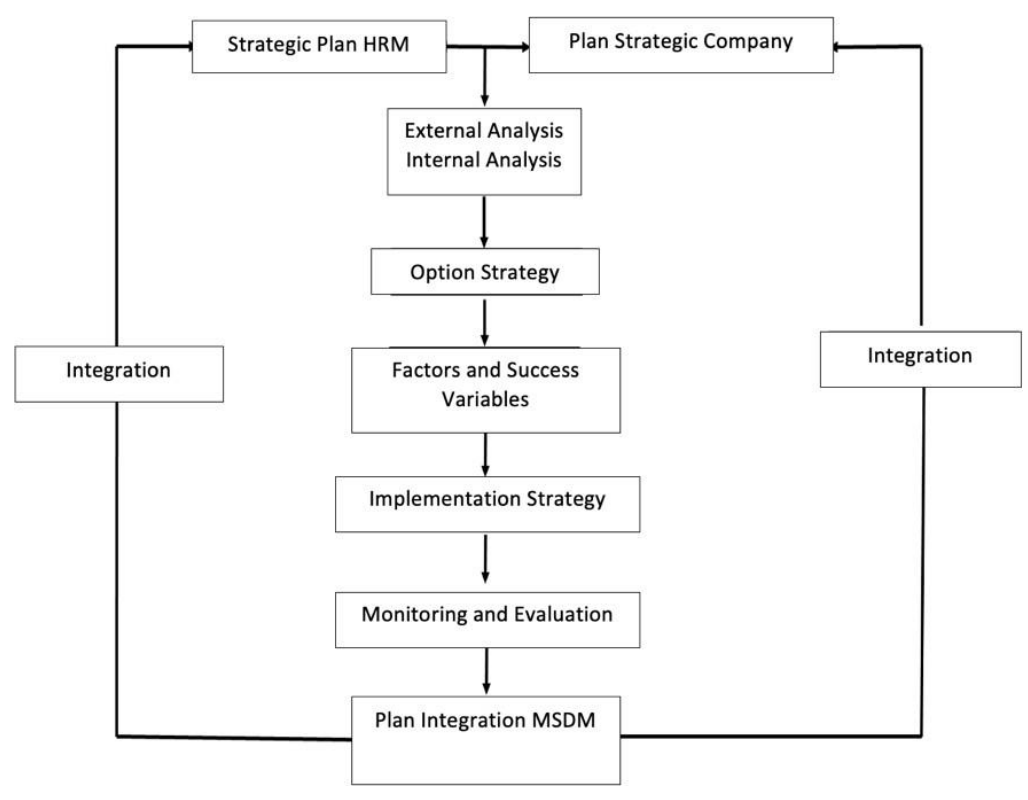

Figure 2.

The Framework

\section{RESEARCH METHODS}

Qualitative research methods are used for several considerations, first, adjusting qualitative methods is easier when dealing with multiple realities. Second, this method directly presents the nature of the relationship between the researcher and the respondent, third, this method is more sensitive and is more adaptable to a lot of sharpening the mutual influence of the patterns at hand (Moelong, 2017).

Researchers will complement this qualitative research method with a case study approach. Yin (2013) states that case studies are a method of approach to social science research where in general the approach is more appropriate if the main question of a research is about "how" or "why". Objects that can be raised as cases are contemporary in nature, namely those that are ongoing or have been ongoing but still leave a broad, strong or specific impact and influence at the time the research was carried out.

\section{RESULTS AND DISCUSSION Research result}

The authors present the results or data of this research based on the results of thematic coding related to company policies, structures, systems and human resources of PT CSI.

A. Company Strategic Plan and HRD Program 


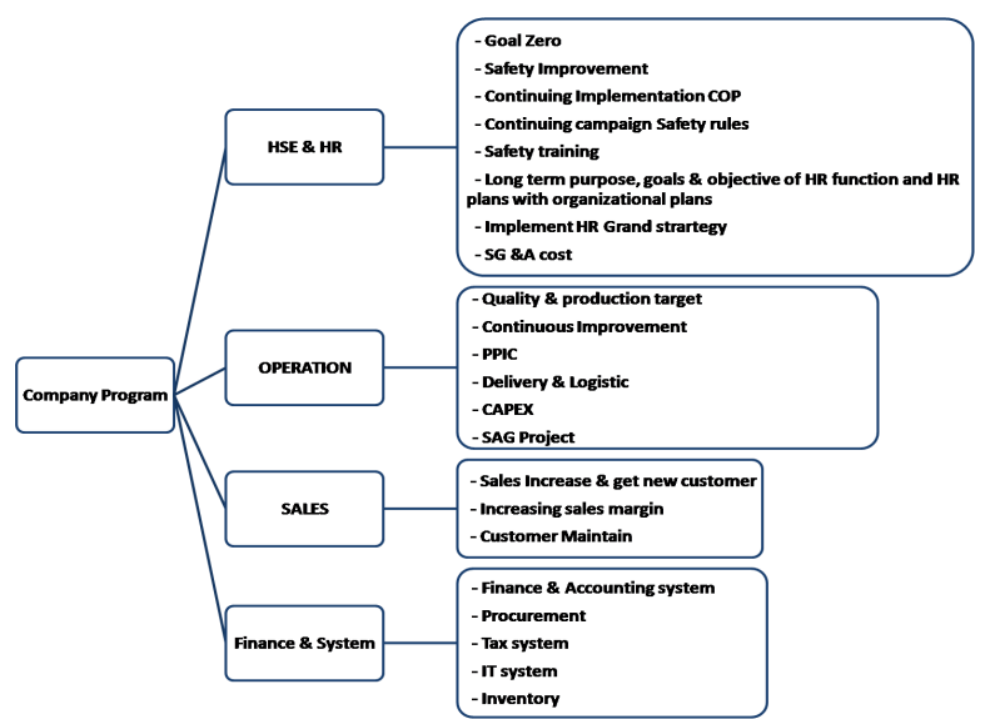

Figure 3

Company Strategic Plan

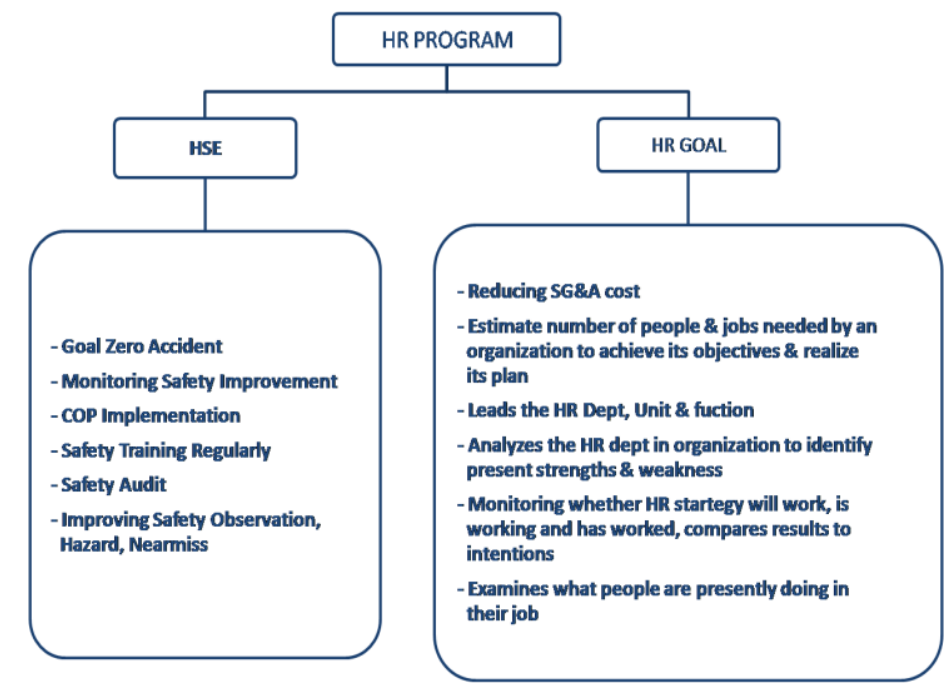

Figure 4.1.2

HR Department Program

\section{B. Company Strategy}

One of the Directors interviewed by the researcher, when asked questions about the company's strategy, emphasized that the company's competitiveness would be achieved through improving and strengthening the quality of human resources in the operational field and fulfilling the licensing and expertise certification aspects.

The company will also increase the capacity of the HR department so that it is able to become a profit center, either directly or indirectly, for example by implementing a classification system for employees and taking an active role in career management, and involving HRD in the company's strategic planning process. The role given by HRD is to provide information, input 
and strategies needed by the company in relation to the company's strategic plans from the point of view of manpower and laws.

The Director's statement is in line with and contained in the company documents governing the POSITION SUMMARY of the HRD Department which reads as follows;

$\checkmark$ Planning and developing HR management policies and systems, as well as coordinating and controlling the implementation of HR management functions throughout the company in order to support and improve HR performance in achieving company goals and in carrying out all work must always prioritize safety aspects.

$\checkmark$ Coordinating and controlling the implementation of HR functions throughout the company to ensure that everything is in accordance with the strategies, policies, systems and work plans that have been prepared in accordance with applicable government regulations and regulations.

The company also provides space for innovation and initiative in developing HR management strategies. The implementation for the use of HRIS and E leave system is a form of giving authority to HRDs. In addition, HR is given the flexibility to organize the training needed for employee development.

\section{Structure / Organization}

The HRD Director emphasized that the company has a clear and written organizational structure, divided into staff levels, middle management levels and top management levels or Directors. The organizational structure also continues to be developed in order to be able to drive the company dynamically in achieving company goals. Organizational structure is made not rigidly but dynamically following the development and business challenges. Even companies have a tendency to implement a lean and simple organizational structure.

\section{Executed System}

Instructional pattern, this system is used internally in the company relating to the direction of company policies and mission statement leadership. The management of interdepartmental interactions and coordination patterns is carried out in meeting forums which are scheduled or ad-hoc in nature.

Communication patterns are carried out every day through daily meetings with all departments, and if there are related issues delivered in the meeting. Company regulations and related regulations are the main systems used to run an organization which are then translated into key performance indicators, as a control and evaluation tool. All internal rules and processes can ensure the team stays on track.

\section{E. Company Values}

Interviews with the HRD Director and Operations Director illustrate that the company is very committed and dedicated to always innovating, at the forefront of business, commitment to health and safety without compromise, having a positive impact on local communities and greater environmental sustainability, through every aspect of the company.

The company is also committed to building a safe and happy workplace and is always focused on customer needs and satisfaction. These values are the basis of the movement of the 
company and all the human resources in it. With these values, the company hopes to remain competitive and become the choice of customers.

\section{F. Leadership Style}

Structural and participatory leadership is applied in the company to create a dynamic and safe and happy work environment so that all of its human resources can be creative and innovative so that it can generate added value for the company and customer satisfaction. According to the informants, this leadership style is able to increase the role and function of each element of the organization so that it has the same rhythm of motion in achieving company goals.

\section{G. Human Resources}

Companies value and empower employees because they recognize that employee success is the company's success. Human resources are built through a business culture that seeks to employ diverse, talented and dedicated men and women who continue to learn and grow with the company to create a better future.

The HRD Director explained that there were various obstacles in carrying out the big vision of the company above, namely

1) Recruitment of employees

The location of companies in the regions often recruits employees, especially for operator positions, which causes a stir due to the intervention of external parties such as NGOs who force the recruitment of employees by force.

2) Discipline

The problem that often occurs regarding employee attendance is not on time after lunch time, not when entering the office. Often found employees who are always late returning to the office, or still sleeping after lunch.

3) UMK Salary

Currently, the issue is because the increase in UMK every year is always significant, resulting in a smaller gap between old and new employees. For that we need a strategy from HR to anticipate complaints from employees regarding this matter.

4) Security

One of the most disturbing factors in the company's environment is the issue of security, where the company is often undermined by external parties, such as NGOs and the community, which often causes inconvenience.

5) Training

The results of training for employees are often not optimal, meaning that it does not have a significant impact on employee productivity

6) Change Management

PT CSI is a foreign company. Corporate Global management often changes its management. This often makes it difficult for some employees to cope with change, and sometimes has decreased productivity. A similar opinion was also conveyed by the operational division that HRD needs to increase people excellencies, namely;

- Career management, job leveling \& people review

- Application of a skills development system according to position level, for example: 

a. Management trainee program
b. Supervisor development program
c. Program development manager
d. Other operational trainings

The study also found the fact that HRD faces obstacles and challenges in the HR management process as follows;

a. Slim \& simple company organization

The company organization is lean and simple, resulting in career paths for employees that require a very long process, so sometimes companies lose potential employees.

b. Low competency \& skills of old employees

Some of the employees of PT CSI are employees who have worked for a long time, they joined at the beginning of the company. At that time, HRD recruited employees for operator positions with low qualifications and education, so that at this time they were difficult to improve their competition.

c. Failure of the training process

Sometimes it is found that the training results for employees are not maximal, meaning that it does not have a significant impact on employee productivity

\section{H. Key Skills}

The company improves the core skills of employees in supporting the business. Companies carry out various trainings to address skills gaps. Implementation of a Training Needs Analysis is carried out to see the gaps that occur. The types of training conducted by the company include;
a. Leadership Training
g. Operation Matrix
b. Company Regulation
h. Contractor Management
c. $\mathrm{AB} \& \mathrm{C}$ Training
i. Lubricant \& Grease
d. Basic First Aid
j. Electrical Safety
e. Isolation Level 1 and 2
k. Confines Space
f. Team Building
1. Puncture Surface

\section{Data Analysis}

Referring to the research data above, the implementation of Human Resource Management has not been oriented towards comprehensive investment. It is evident that he still considers HRD as a cost center, even though there has been integration and adaptation to the entire process of increasing competitive advantage. HRD companies have been involved since the planning process. The day-to-day practice of Human Resource Management does not appear to fully describe the integration with the needs of organizational strategy. The results also show that at the practical level HRD has a two-way relationship with policy makers, meaning that the problems and impacts that arise in HR management are considered in the strategic plan formulation process. The two-way relationship occurs through the image below;

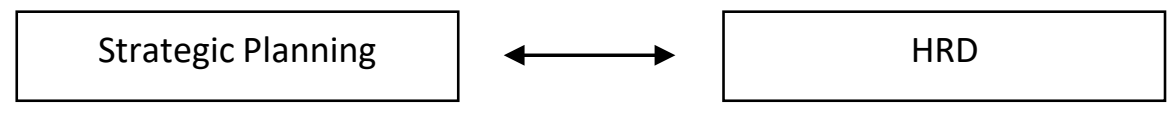


Strategic planning is communicated to HRD. Then the HRD responds by analyzing the problem and the impact of the strategic plan on HRD and then informing it back to the strategic planner. Strategic planning makes strategic decisions and informs back to HRD to develop systems and / or programs that support the implementation of the strategic plan.

In terms of policy and organization, the Company has a plan for the integration of HR Management and a comprehensive corporate strategic plan. This needs to be done through a change in HRD from a cost center to a profit center, so that HRD has a strong policy foundation in developing an appropriate integration model.

The HRD department needs to improve and strengthen its positioning so that it has a maximum contribution. Strengthening the HRD institution includes;

1) HR practices that make organizational HR more competitive and comfortable to work with

2) HR policies and activities need to be based on a stronger mastery of HR concepts and techniques

3) HRD needs to encourage the achievement of results from organizational performance through HR programs. HR must also have business results from all its work processes.

4) Transforming HRD duties from supervisory company policies and making employees happy to developing employee capabilities and commitment

5) HRD staff need to improve their argumentative and challenging ideas and be able to show a supportive attitude

6) HRD needs to strengthen its integration into other departments by acting as a catalyst for change in business processes from the HR side

7) Strengthening the role of HRD as a strategic partner, by adjusting the HR strategy to the organization's strategy

On the technical aspects of HRD, it is necessary to develop an HR program including;

a. Management of Company Infrastructure

$\checkmark$ Manage and develop planning guidelines and policies to manage HR effectively.

$\checkmark$ Acting as a consultant for other departments

$\checkmark$ Responsible for continuous improvement in an area of expertise

$\checkmark$ Follow and focus on organizational dynamics

b. Management of Employee Contribution

$\checkmark$ Speak on behalf of employees and the company

$\checkmark$ Understand the dynamics that occur with employees and focus on their needs and are easy to find when employees want to have a dialogue

$\checkmark$ Focus on skills in helping employees work

$\checkmark$ Provide all the resources needed by employees in order to increase commitment in achieving company goals

c. Strategic HR Management

$\checkmark$ Have knowledge of the company's business and its implications for HR and drive strategic change to support business strategy

$\checkmark$ Be sensitive to external and internal dynamics and focus on developing and managing change and the needs of the organization to be effective and efficient

$\checkmark$ Building Human Capital

$\checkmark$ Develop a talent recruitment system 
$\checkmark$ Develop a system of knowledge sharing and training that is evenly distributed at every element and level of the organization

$\checkmark$ Designing leadership quality development programs

$\checkmark$ Develop employee benefit programs to generate engaging, energizing and commitment

$\checkmark$ Learn unconventional techniques in the organizational transformation process

HRD also needs to evaluate and re-map the job descriptions of each position, providing notes for potential employees. Conduct training evaluations of all trainings conducted by the company and carry out training in accordance with the needs and competencies of employees.

For old employees who have worked for more than 15-20 years, where their abilities \& skills are no longer possible to improve with trainings, better options must be provided, or the company can offer early retirement for these employees.

\section{Discussion}

The integration of HR functions in the company's business strategy refers to efforts to redefine the organizational conditions, roles and capabilities of the organization regarding business issues. This can be done by clearly defining the roles, behaviors, activities and responsibilities of each employee so that employees are able to improve their performance by mastering or having talents and expertise in accordance with their field of work, being able to develop themselves, working together in a work team so that they can make a big contribution. in improving the overall performance of the company. Increasing company performance will have a positive impact on the survival and development of the company.

Efforts to integrate HR functions in the company's business strategy can be carried out through three approaches, namely first, matching or adjusting managerial styles or personnel activities, second, predicting labor requirements by providing targets. definite strategic objectives or environmental conditions, and third, providing the means of integrating human resources in an overall effort to adjust the company's strategy and structure.

Involving the HR Management function as a whole in the formulation and implementation of company strategy, it is hoped that it can identify various company problems related to HR from the beginning of the formulation process so that the company can determine the right choice of strategy and determine steps to overcome it so that strategy implementation can run effectively. The HR Management function has a great impact on strategy implementation by developing and aligning HR Management practices which ensure that the company has developed employees with the necessary skills so that they can carry out their duties effectively which in turn can support the achievement of the company's strategy.

The centrality and importance of organizational learning and HRD is described by Harrison (2013) through a training and development scheme as a strategic process. McCracken also explains this in his statement that the learning process occurs at the individual, group and organizational level, and the main key to SHRD is how to create an environment that supports the spirit of learning, which in turn will encourage learning and development that supports improved performance. This statement places learning as an organizational capability that causes the organization to learn faster than competitors. So that this can be a competitive advantage. 
The difference between operational and strategic roles exists in a number of HR areas as explained by Robert L. Mathis, John H. Jackson (2012). Strategic HR roles require HR professionals to be proactive in dealing with business realities and focus on future business needs, such as workforce planning, compensation strategies, and HR performance. Many executives, managers, and HR professionals increasingly see the need for HR management to be a greater strategic contributor to the success of an organization's "business".

Strategic HR management refers to using employees to gain or maintain a competitive advantage. Since business strategy influences HR plans and policies, consideration of human resource issues must be part of the strategy formulation process. It is important to identify competitive advantage opportunities that suit existing employees or to assess strategic alternatives given the organization's current human resource capabilities. HR managers should scan the environment to find out what workforce skills are available and what are not. HR professionals should also be able to estimate waiting times to match a workforce shortage or surplus. In short, HR must be involved in implementing a strategy that influences and is influenced by people. In brief, the process of preparing the HR strategic development plan can be explained as follows;

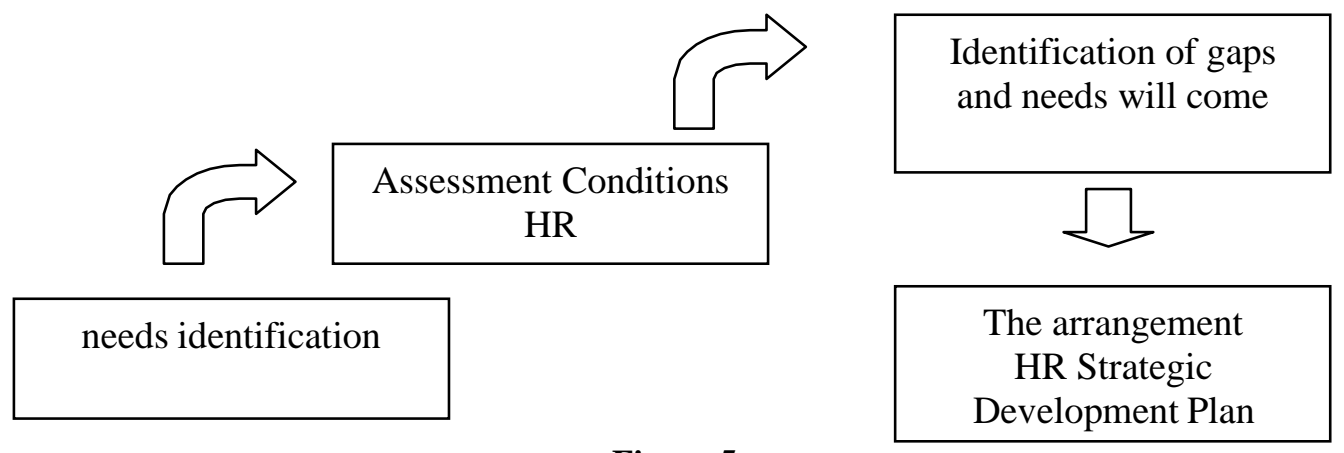

Figure 5

Strategic HR Program

The tactical steps that need to be taken are;

a. Develop Organization Capability (HC) architecture, including;

$\checkmark$ Vision and Mission

$\checkmark$ Corporate value

$\checkmark$ Organization goals

$\checkmark$ Fundamental beliefs

$\checkmark$ Principles of organization

b. Change in mindset at management level so that commitment to Building HC and change in mindset for middle line managers to support building HC

c. Compilation of a competency dictionary that supports organizational capacity development and mapping of competency gaps against current human capital

d. Designing HR systems to increase employee commitment, consistency, competence and performance, including;

$\checkmark$ Job design

$\checkmark$ Performance management 
$\checkmark$ Rewards and recognition

$\checkmark$ Appraisal system

$\checkmark$ Recruitment and staffing

$\checkmark$ Development and career plant

\section{CONCLUSIONS AND SUGGESTIONS}

\section{Conclusion}

a. The competitiveness of the company will be achieved through improving and strengthening the quality of human resources in the operational sector and fulfilling the licensing and expertise certification aspects.

b. The company will increase the capacity of the HR department so that it is able to become a profit center, either directly or indirectly.

c. The company involves HRD in the company's strategic planning process. The role given by HRD is to provide information, input and strategies needed by the company in relation to the company's strategic plans from the point of view of manpower and laws.

d. Day-to-day human resource management practices do not appear to have fully translated into the needs of organizational strategy.

e. The research results also show that at the practical level HRD has two-way relationships with policy makers, meaning that problems and impacts that arise in HR management are considered in the process of formulating strategic plans.

\section{Suggestion}

a. PT. CSI needs to improve and strengthen the positioning of the HRD Department in order to make a maximum contribution. Strengthening the HRD institution includes; HR policies and activities need to be based on a stronger mastery of HR concepts and techniques. HRD needs to encourage the achievement of results from organizational performance through HR programs. HRD must also have business results from all its work processes. HRD needs to strengthen its integration into other parts by performing a catalytic function for changes in business processes from the HR side. Strengthening the role of HRD as a strategic partner, by adjusting the HR strategy to the organization's strategy. HRD needs to formulate a strategic HR development plan, which is integrated with the company's strategic plan.

b. In HR Management learning about the integration techniques of HRD programs and company strategic programs, it needs to be taught specifically and deeply.

c. Further qualitative research on HR systems and programs to increase employee commitment, consistency, competence and performance is necessary. Learning organization as an organizational capability that can increase competitive advantage also needs further qualitative research

\section{REFERENCES}

Antoni Ludfi Arifin (2017), Institute of STIAMI, Development Strategy Of Human CapitalOf PT KIMIA FARMA (Persero) TBK, International Journal of Human Capital Management, Vol 2, December 2017. 
Bogdan, R.C \& Biklen, S.K.B. (1998). Cualitative Research for Education toTheory and Methods. Allyin and Bacon, inc. Boston

Creswell, John W (2015). Penelitian Kualitatif \& Desain Riset. Yogyakarta : Pustaka Pelajar.

Danang Sunyoto (2015) Management dan PengembanganSumberDayaManusia .Yogjakarta :Centre for Academic Publishing Service

Eisfeldt and Papanikolaou (2013) Organization capital and the cross section of expected returns

Gina MayasariSujaya and AurikGustomo (2013) School of Business and Management, InstitutTeknologi Bandung, IndonesiaProposing Human Capital Strategic Initiative in Creating Value ofCompetency Dictionaryat PT UNITED TRACTORS (TBK), The Indonesian Journal of Business Administration Vol 2, No 13, 2013:1580-1589

Glesne, C., \& Peshkin. (1992). Becoming qualitative researchers

Haeryip Sihombing, AdiSaptari, Moh. Yuhazri bin Yaakob (2010), UniversitiTeknikalMalaysia Melaka, Business Strategies Through Fit Management Of Human Capital as Competitive Advantage, Journal of Indoensian Economy and Business, Volume 25, Number 2,2010,170-189

Hitt, Ireland, Hoslisson (2007), Strategic Management, Competitiveness and Globalization IwanSukoco dan Dea Prameswari (2017),Faculty of Social and Political Science,Padjadjaran University,Human Capital Approachto Increasing Productivityof HUMAN Resources Management, Journal AdBispreneur Vol 2, No 1, April 2017

Barney, J.B and Hesterly, William S. (2015). Strategic Management and Competitive Advantage. United States of America: Pearson Education Limited.

Kaswan (2012) Manajemen Sumber Daya Manusia untuk Keunggulan BersaingOrganisasi.Graha Ilmu, Yogyakarta

Lexy J. Moleong, Dr. M.A., Cetakan: 37, 2017, Metodologi Penelitian Kualitatif (Edisi Revisi), Remaja Rosda Karya, Bandung

Mantja. (2007). Etnografi, Desain Penelitian Kualitatif Pendidikan dan Manajemen Pendidikan. Malang: Elang Mas.

Moriarty, J 2011, Qualitative Methods Overview. SSCR Methods Reviews, National Institute for Health Research School for Social Care, London.

Nasution (2007), Metode Research Penelitian Ilmiah, (Jakarta: Bumi Aksara)

Noe, Raymond A., John R. Hollenbeck., Barry Gerhart and Patrick M. Wright. 2011. Fundamentals of Human Resource Management. New York: McGraw Hill.

Rahmat (2013). Statistika Penelitian. Bandung: Pustaka Setia

Rayadi (2012).Faktor Sumber Daya Manusia yang Meningkatkan KinerjaKaryawan dan Perusahaan di Kalbar. Jurnal EKSOS. Vol.8 No.2.Pontianak: AMIK Panca Bhakti.

Robert K. Yin, 2013, Design and Methods. SAGE Publications, Incorporated

Robert L Mathis, John H Jackson, (2012), Human Resource Management, Edisi Pertama Salemba Empat, Jakarta

Sugiyono. (2014). Metode Penelitian Pendidikan Pendekatan Kuantitatif, Kualitatif, dan R\&D. Bandung: Alfabeta

Syahbudi, Hamidah, YettiSupriyati (2018), , Indonesian Naval Doctrine Development, Education and Training Command State University of Jakarta,Organization CultureofSaka BahariScout Movement, International Journal of Human Capital Management, Vol 2, No 1, July 2018. 
Wijaya, Sheleen. "Pengaruh Organizational Learning Terhadap Competitive Advantage Melalui Accounting Information System Pada Perusahaan Manufaktur Terbuka." Business Accounting Review3.2 (2015) 